\title{
Agripreneurship and Agricultural Labour Market: Agripreneurial Intentions among Undergraduate Students in Ondo State, Nigeria
}

\author{
E. S. Ikuemonisan and A. E. Akinbola
}

ABSTRACT

This study examined agripreneurial intentions among students in the state-owned tertiary institutions in Ondo State. The study profiled students' perceptions of learning (SPOL), teachers' impact (SPOT), and mentorship and explored the effects of these on their agripreneurial intentions. Both descriptive and inferential statistics were used to analyze 120 students, who were randomly selected from the two state-owned tertiary institutions. A logistic regression analysis was performed to assess the effects of SPOL, SPOT, mentorship, as well as other socioeconomic characteristics, on students' likelihood to have agripreneurial intentions. The study revealed that SPOL, SPOT \& age significantly increased the likelihood of students having agripreneurial intentions, while perceptions of mentorship and the number of graduates in the family decreased it. Although the SPOL and SPOT were positive and statistically significant, the weak effects of the mean scores suggest that SPOL and SPOT should be improved upon to enhance students' interest in agripreneurship

Submitted : May 04, 2021

Published : May 31, 2021

ISSN: $2684-1827$

DOI: 10.24018 /ejfood.2021.3.3.298

E. S. Ikuemonisan*

Adekunle Ajasin University, Akungba Akoko, Nigeria.

(e-mail:

edamisan.ikuemonisan@aaua.edu.ng)

\section{A. E. Akinbola}

Adekunle Ajasin University, Akungba Akoko, Nigeria.

(e-mail: yoseakinbola ${ }^{@}$ gmail.com)

*Corresponding Author
Keywords: agripreneurial intention, labour supply, students' perception of learning, students' perception of teachers, mentorship.

JE Classification: E24, I23, J21, L26, Q13

\section{INTRODUCTION}

In view of the rising population and economic growth in sub-Saharan Africa, the increasing demand for food and other agricultural produce requires more investments and increased productivity in the agricultural sector [1]-[4]. According to Keynes, increase in demand is inevitably triggered by increase in income. Therefore, to increase the income of farmers and other actors in the agricultural sectors, they must be creative and enterprising in terms of adding values to food and other agricultural produce. As agribusiness folks earn more income, they spend more on food and other needs thus, systematically escaping hunger and poverty. Similarly, they save more and also create more investment opportunities. Therefore, to sustain the income and consumption chain in one hand, and savings and investment chain on the other hand, more enterprising people (entrepreneurs) should be involved in the agricultural value chains. However, Agricultural activities characterized by low productivity, low investment and inefficient use of production resources [5], [6] and poor economic experience being witnessed in SSA is largely dictated by the limited entrepreneurial activities [7], [8]. The low productivity arising from the above is a disincentive to participants and discouragement for intending investors in the post farm agribsuiness. All these have cumulative effects on the rising unemployment rate in the sub-region [9]

In order to solve the problem of low productivity and inefficient use of production resources, farmers and other actors in agricultural value chains adapt and become accustomed to the mindset of an agripreneur [10], [11]. Therefore, farmers, processors and market folks focus more on the agribusiness needs with a view to enhancing commercial activities in agri-trade and trading [12]. This approach will not only increase agricultural productivity but will also sustain production. Similarly, [13] submit that entrepreneurship-oriented intentions are useful precursors for entrepreneurial actions. The literature also suggests that, increase in entrepreneurship activities cause decline in poverty and hunger. In view of the importance of entrepreneurship, it was integrated in the educational curriculum for all undergraduates in Nigerian universities as one of the compulsory courses that must be passed before being awarded any degree certificate. The idea about this is to help students cultivate and grow their entrepreneurial skills regardless of the choice of their course of study. 
Fundamentally, agripreneurial intention is related to the risk taking in order to own an agribusiness and be selfemployed [14] but the concept of agripreneurship is not the same as that of agribusiness. This is because not all agribusiness ventures appropriately suite the features of agripreneurship [15], [16]. Since agripreneurship is about risk taking, therefore, in our concept of agripreneurship, opportunity is considered an integral part of what is agripreneurial driven by the desire to add value to the agricultural value chains [17]. [16] as cited in [18] defined the field of entrepreneurship as the "scholarly examination of how, by whom, and with what affects opportunities to create future goods and services are discovered, evaluated, and exploited" We consider agripreneurship to be about finding, founding and funding of a new agribusiness venture. This plays an important role in the building of a sustainable business process [11], [19]. A number of authors have attempted to define entrepreneurial intention [18], [20]. It is from these conceptual positions a definition for agripreneurial intention is extrapolated for the purpose of achieving the objectives in this study. Therefore, agripreneurial intention is a condition where individual's thoughts and actions are systematically guided towards self-employment as compared to pursuing employment prospects in an existing organisation.

It has become evidently clear that Nigeria as well as other countries in SSA needs to raise more entrepreneurs, who exhibit common traits like risk taking; hard work; clear ambition; and creativity with problem solving-skills, from the current pool of favourable youth demographic population in the sub-region. This will enable Nigerian economy to benefit in the following areas: increase in productivity, resilient systems that leverage on finance opportunities, and in-depth economic inclusive growth which will result in economic growth. However, there are concerns that lack of interests in agriculture as a course discipline by the students and lack of interest to select agribusiness as a career by students studying agriculture [21] could be serious threats to raising more enterprising young agribusiness folks and agripreneurs.

Regrettably, evidence on the factors influencing students' Agripreneurial intention among Nigeria students is scarce in the literature. Besides, since the establishment of Faculty of Agriculture in the two state owned universities in Ondo State, there is no study, to the best of our knowledge, that has been carried out to explore the agripreneurial intention of students studying agriculture in these institutions. In addition, literature on perception of these students on mentoring, learning and teachers' impact on agripreneurial intentions of students is scanty. A robust knowledge of these can be very useful for policymakers and operators of university system to improve the Agricultural education system in Nigeria with the ultimate goal of raising a new generation of agribusiness folks.

\section{OBJECTIVE OF THE STUDY}

The overall objective of the study is to determine factors that influence the agripreneurial intention among undergraduate students in state owned universities in Ondo State.
The specific objectives are:

1. To profile the socio-economic characteristics of respondents.

2. To examine the status of respondents' most influential mentors.

3. To assess student' perceptions on factors influencing the development of agripreneurship in Nigeria.

4. Determine factors that influence students' agripreneurial intention.

\section{HYPOTHESIS}

$\mathrm{HO}_{1}$ : There is no significant difference between the socioeconomic characteristics of those who have agripreneurial intention and those who have no agripreneurial intention

$\mathrm{HO}_{2}$ : There is no significant difference between the perceptions of those who have agripreneurial intention and those who have no agripreneurial intention.

\section{LITERATURE REVIEW ON FACTORS INFLUENCING AGRIPRENEURIAL INTENTION}

Quite a number of factors have been identified as both motivating and inhibiting factors for individuals with entrepreneurial intentions. Entrepreneurship encompasses general business initiatives to add value to existing produce or product to produce a new commodity while agripreneurial initiatives are limited to the field of agriculture. Therefore, agripreneurship is a subset of entrepreneurship. Therefore, in view of the scarce literature on agripreneurship, the study reviews the literature on entrepreneurship on the understanding that the principles that guide the two concepts are basically the same except on some peculiarity which this study attempts to address.

The several intersections between entrepreneurship / agripreneurship and labour markets have been explored in the literature [22]-[24]. [24] highlighted two major ways by which agripreneurs get involved in the labour market dynamics as: occupational choice (participation in agripreneurship) and hiring labour. [22] found an empirical evidence about the relationship between entrepreneurship and employment statistics. This argument was approached in two ways. One, unfavourable labour market conditions pushes people to become entrepreneurs. Thus, as the number of entrepreneurs increases, the number of people seeking to be employed decreases. Therefore, entrepreneurship rate is inversely related to employment rate [23]. It can be inferred that, the intention to become an entrepreneur/agripreneur is an attempt to exit labour market. Situating this in Nigerian economy context, where the labour market is already saturated with unemployed graduates and the number of jobs opportunities in the public and private sectors is declining, how to encourage the youths to become entrepreneurs should be a strategy the policymakers should consider. Above all, the agricultural sector of the economy needs more enterprising and innovative young minds (agripreneurs) to develop and drive the new agribusiness initiatives being proposed by the policymakers. The second leg of the argument proposes that, being in charge of the allocation of production resources including labour and capital gives entrepreneur/agripreneur 
that opportunity to build nest of economic activities that can enhance enterprise growth, which enables them to employ more labour. It implies that as entrepreneurs increase their economic activities, it leads to more workers being employed on paid employment. Thus, expanding entrepreneurial economic activities lowers the level of unemployment. Consequently, an agripreneur gets profit as a reward for the risk taken, while a hired labour get wage or salary as the reward working without taking any risk.

Findings revealed that students' entrepreneurial intentions have been largely influenced by cultural context [26] and [27]. According to 18 those who showed keen interest and desire to be entrepreneurs have better success stories that those who are perceived to have high ability. This line of thought harps on the importance of the willingness of an individual to be an entrepreneur. A resourceful entrepreneur is an asset to his/her employer. Studies have also shown that individuals with entrepreneurial abilities (and for that matter, attitudes about risk, work, and independence) are also likely to be highly valued by employers and may be offered sufficient financial incentives to remain an employee [28]. Furthermore, employees with higher earnings are less likely to make the decision to leave their current employer. However, if they do decide to leave, they are more likely to create a new venture than those with lower earnings who leave their current employer [29]. [30] found that low competence of instructors, absence of curricular capacity to support training, lack of infrastructure, unfavourable policy support are some of the discouraging factors that affect entrepreneurship development.

Exploring the relationship between entrepreneurial intention and socio-economic variables, [20] revealed that there were no statistically significant relationships between students' entrepreneurial intention and socio-economic variables like age, gender, cultural background, etc. However, [31] found that more males have entrepreneurial intention than females. On the importance of entrepreneurial education, evidence from the literature showed that entrepreneurship education is a significant factor influencing entrepreneurial intention [31]-[33]. On the other hand, [34] opined that cognitive variables including academic performance have positive effects on career related intentions. In a similar position, [25] argued that situational factors such as educational environment have influential effects on career related intentions. [35] found that needs, values, wants, habits and beliefs affect people's decisions including career decision and entrepreneurship intention.

The works of [22] and [36] have further elucidated on the two popular theories that have been consistently used to advance the motivation for entrepreneurship (push and pull theories of entrepreneurial motivation). The recessional push theory assumes that people are motivated to become entrepreneurs as a result of negative situations in the labour market. Such negative factors connected with the situation in the labour market activate people's entrepreneurial talents. However, the pull theory states that the desire and quest for attractive and potentially profitable business opportunities often lure people into entrepreneurial activity; thus a given person becomes an entrepreneur as a result of the positive effects of economic stimuli. This underscores the difference between opportunity entrepreneurs and necessity entrepreneurs [37], [38]. This kind of entrepreneurial motivation can affect individuals' the entrepreneurial aspirations [22]. According to [39] and [40], necessity entrepreneurs are less oriented towards innovation and growth.

Experts have opined that having more agripreneurs to champion the cause of smart agribusiness can result to a more efficient use of production resources, high productivity, and competitive agribusiness subsector in sub-Saharan Africa [41]. These are precursors to eliminating hunger and food insecurity as well as unemployment and poverty, particularly among rural households in Nigeria. Similarly, policymakers have identified agriculture as an area to unleash the entrepreneurial potentials in the youth demographic distribution. Agripreneurship is a widely acceptable model to raise new generation of self-driven individuals who are interested in agribusiness particularly in sub-Saharan Africa with a view to enhancing productivity, which is key to achieving the Sustainable Development Goal No 2. According to [42], Agribusiness is described as a large scale agricultural activities, which encompasses the cultivation, processing and distribution of agricultural outcomes in addition to the manufacturing of farm machinery, equipment and input supplies. Agribusiness orientation is capable of integrating a systemic order that can offer that opportunity to address, among other challenges, lack of well-structured succession plans to replace the ageing farmers by making the sector attractive to new entrants. On the other hand, the phrase "smart agribusiness" is relatively new to agriculture lexicons across countries in SSA. Smart agribusiness is a modern approach where agricultural activities are driven by relevant knowledge and technology with a view to optimizing production [43], [44] and actors in the sector can also be guaranteed of sustainable means of livelihood.

According to [45], [46] and [47], smart agribusiness driven by agripreneurs is a pro-economic tool that has the potentials to address hunger and poverty in low income countries. It is a precursor to achieving sustainable agricultural production through efficient use of production resources and consistent evaluation of production process [48] including distribution of produce and products to final consumers. In the literature, smart agriculture has various dimensions, and all these work together to improve the capacity to increase farm productivity and increase food accessibility and affordability through value creation [41]. In the same vein, entrepreneurship in agriculture relates to the "creation of an innovative and economic organization for growth under conditions of risk and uncertainty" [49]. The concepts of smart agribusiness and entrepreneurship in agriculture have metamorphosed to form a new concept called agripreneurship. This concept is one of the key models required to solve the protracted problem of inefficient agricultural and food production system. However, experts have argued that lack of agripreneurs as a major missing link to the development of a functional agribusiness industry across countries in SSA [49]. In view of this, there have been calls for more agripreneurs to participate in the business of agriculture. Scholars are convinced that this strategy can adequately solve the problem of food insecurity that is confronting the low income countries including Nigeria [41]. 
An agripreneur is a risk-taker who had acquired or unrepentantly willing to acquire sufficient skills, good enough to initiate an agribusiness of interest and nurture the same sustainably. In brief, agripreneurship focuses on how to add value to food and other agricultural products. As many agripreneurs are involved in agriculture, and with appropriate policy strategy in place, sustainable production is guaranteed. Consequently, as more values are added to agricultural products, more transient incomes are received leading to more savings which will inevitably lead to increase in investment. Therefore, the concept of agripreneurship development refers to the creation of a wide pool of personal agribusiness initiatives designed to provide a variety of goods and services as the demand may be. Countries that have witnessed marked agripreneurship development have achieved that through the synergy between the industry and the research/tertiary institution under the radar of proactive policymakers. It should be noted that while it is true that all agripreneurs are actors in agricultural sector, not all those involved in the agricultural sector is an agripreneur. What differentiates an agripreneur from other actors in the agricultural sector is the unrelenting desire to take business initiatives, regardless of the risk involved, to improve agribusiness performance. To achieve these, value must be added to existing farm produce of interest(s). Therefore, in this study, anyone; a farmer, an agric processor, or an agritrader/market folk, who adopts an entrepreneurship model that helps in creating a local business cluster with a view to sustainably increasing production through efficient use of productive resources is considered an agripreneur.

In summary, agripreneurship development fostered by individuals with agripreneurial intention is a precursor for smart agribusiness.

\section{RESEARCH METHODOLOGY AND DESIGN}

The study was carried out in Ondo State, Nigeria between November and December, 2020. Ondo State is richly endowed in natural resources and wide range of fertile land for agricultural activities hence the attractiveness of the land for farming activities. Its history as the largest producer of cocoa in Nigeria has not been re-written. Besides crop farming, fishing is another popular occupation in the southern part of the state where the longest coastline in the country is situated. The state has two distinct seasons, raining and dry season with temperature ranging between $23^{\circ}-26^{\circ}$, and annual rainfall of 2,000 mm down south and close to about 1,150 up north [50]. The state ranked very high among states with highly educated people, and with a population of about 3.4 million people [51], the state has about 10 accredited tertiary institutions. Four of these institutions are owned by the state to advance tertiary knowledge among the youths. However, rate of unemployment in the state is relatively high $(11.4 \%)$.

\section{RESEARCH DESIGN}

A research survey approach, where individual students were expected to give quantified responses to questions itemized on a list of questionnaires in line with the approach used by [52] and [20], was deployed in this study. It is a well- established fact that in Nigeria, B. Agriculture Programme is run for a period of 5 years. However, students in this programme only begin to understand and appreciate the objectives of agricultural education from 300 level. At this stage, the students have begun to learn skeletally from the teaching and research farm. At 400 level, students are fully mobilized to teaching and research farm for a whole semester after which they are posted out to agribusiness ventures for real field experience. Upon returning, in 500 level, students are expected to have gained enough experience and be ready to apply knowledge gained to their project work. Therefore, a sample of 120 students were drawn from 2 universities in Ondo State (Olusegun Agagu University of Science and Technology [OAUSTECH] and Adekunle Ajasin University, Akungba Akoko [AAUA]). These two schools were purposely selected because they are the only two universities that run a B.Agriculture programme in the state. Five (5) students were randomly selected per department (4 Depts) per level (3 Levels) using their departmental register. Given that there were four departments per school, we then have 20 students (5 students x 4 departments) per level. When the selection was done across the three levels $(300,400 \& 500$ levels) and the two universities, we have 120 students in all.

A structured questionnaire was designed to elicit responses on socio-economic characteristics, agripreneurial intention, knowledge about various meanings of agripreneurship, profile of perception of learning environment, perception of teachers, and mentoring, cognitive variables and academic performance of the respondents. Questions related to perception of mentoring, learning environment and perception of teachers were ranked variables set on a 5 point likert scale (Strongly agree $=4$, agree $=3$, undecided $=3$, disagree $=2$ and strongly disagree $=0$ ).

For various statistical analyses required in this study, IBM's SPSS version 23 software [73] was used. The first stage of data analysis employed descriptive statistics to derive percentage frequencies of responses. All statistical tests were done at a $95 \%$ confidence interval.

\section{ANALYTICAL TECHNIQUE}

The logistic regression model, as proposed by [53], which assumes the probability of respondents' preference for agripreneurship intention $(\mathrm{P})$ is expressed as:

$$
P_{i}=\frac{e^{z_{i}}}{1+e^{z_{i}}}
$$

The probability of respondents' no agripreneurship intention was expressed as $\left(1-P_{t}\right)$.

$P_{i}$ ranges between zero and one and it is non-linearly related to $z_{t}$ agripreneurial intention. Put succinctly, Yes, agripreneurial intention $=1$; No agripreneurial intention $=0 z_{t}$ is the stimulus index which range from minus infinity to plus infinity, and it is expressed as:

$z_{i}=\ln \left(\frac{P_{i}}{1-P_{i}}\right)=\beta_{0}+\beta_{1} X_{1}+\beta_{2} X_{2}+\beta_{3} X_{3}+\beta_{4} X_{4}+\cdots \beta_{7} X_{7}+\mu$ 
To obtain the value of $z_{i}$, the likelihood of observing the sample was formed by introducing a dichotomous response variable. The explicit logit model is expressed as:

$Z_{i}=\beta_{0}+\beta_{1} X_{1}+\beta_{2} X_{2}+\beta_{3} X_{3}+\beta_{4} X_{4}+\cdots \beta_{12} X_{12}+\mu$

$\mathrm{X}_{1}=$ Gender of respondents (Male $=1$; Female $\left.=2\right) ; \mathrm{X}_{2}=$ Number of Graduates in the Respondents' family, $X_{3}=$ Age of respondents (number of years); $\mathrm{X}_{4}=$ Students' perception on mentorship after gaining admission into university (scale); $\mathrm{X}_{5}=\operatorname{SPOL}\left(\right.$ scale), $\mathrm{X}_{6}=\mathrm{SPOT}$ (scale), $\mathrm{X}_{7}=$ CGPA .

\section{APRIORI EXPECTATIONS}

One factor, among others, that is expected to act as a push to the students' agripreneurial interest in Nigeria is the exposure to entrepreneurship education early in 100 and 200 levels. However, the impact of this exposure, measured by subjective happiness and/or fulfilment, is expected to be contingent on the quality of learning and quality of teachers available for the students [54]. According to [55], mentoring is regarded as one of the best tools for "reducing stress for novice teachers, orientation to curriculum and promoting the creation of better norms of collegiality and collaboration". This has the potential to enhance students' perception to learn and be guided in their career choice. [56] posited that mentoring helps in the resolution of challenges and predicaments, making it more likely that an individual attains his career goals and growth. Therefore, students who are majoring in Agriculture, if well mentored, can be inclined to embrace agripreneurship. Furthermore, [57] found strong reasons to incorporate "adaptive mentorship models that cater for contextual factors in entrepreneurship education aimed at enhancing specific modules of career adaptability and other important entrepreneurial traits". This approach has the potentials to improve students' interest in entrepreneurship and the quest to create employment on their own. Therefore, mentorship was expected to have a positive effect on the students' likelihood to become an agripreneur. More scholars are positive that the age, gender, number of the graduates in the family, size of the family, cumulative grade point average (CGPA) is among other variables that provide positive and statistically significant influence on their subjective happiness triggered by entrepreneurial and career intentions [54], [31], [58].

\section{SOCIO-ECONOMIC CHARACTERISTICS OF RESPONDENTS}

Fig. 1 contains the distribution of respondents by gender. The figure reveals that in OAUSTECH, both male and female are $50 \%$ apiece, while in AAUA, the male is about $38 \%$ and the female is close to $62 \%$ of the sampled population. Since the sampling was restricted to students in 300, 400 and 500 levels, it is difficult to generalize this finding as the reflection of the students' distribution across the Faculty of Agriculture in the concerned universities. However, if the sample is a true representative of the population, it implies that the proportion of both male and female in Faculty of Agriculture in OAUSTECH is equal while that of AAUA indicates more female than male students are admitted into B.Agricultural Programme.

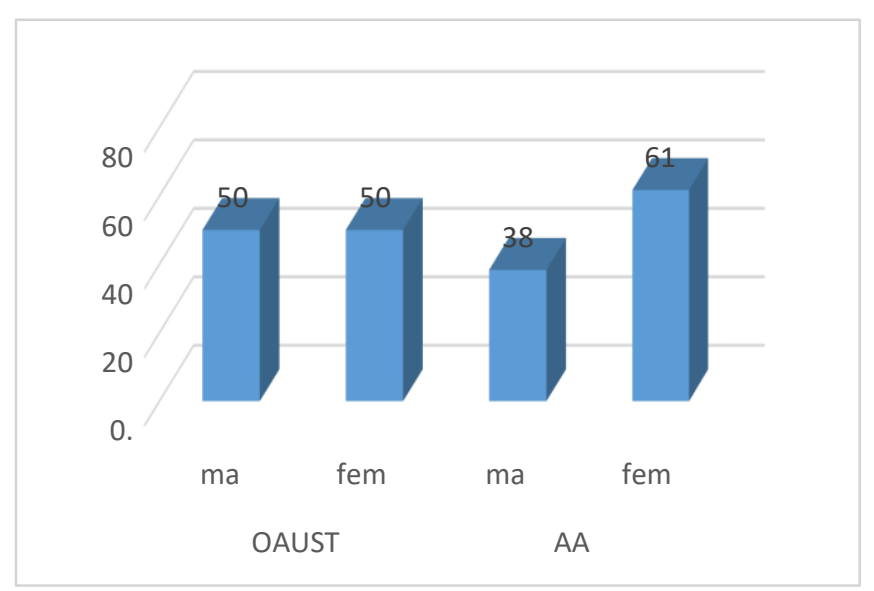

Fig. 1. Distribution of Respondents by Gender. Source: Field Survey, 2021.

\section{A. Distribution of Students by Gender and Agripreneurial Intention}

Fig. 2 reveals the distribution of students by Gender and Agripreneurial Intention. The figure shows that more male $(51.1 \%)$ than female students $(48.9 \%)$ have agripreneurial intention. This finding is in line with the finding of [31].

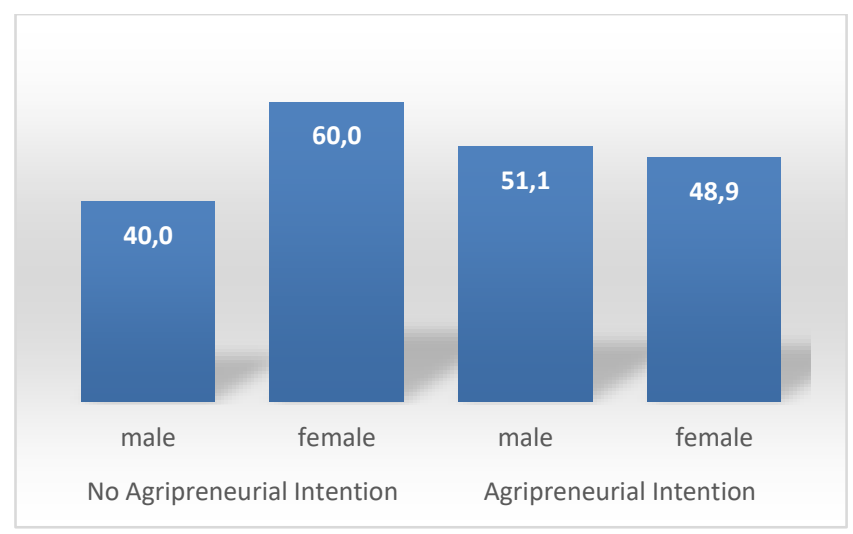

Fig. 2. Distribution of Students by Gender and Agripreneurial Intention. Source: Field Survey, 2021.

\section{B. Comparative Distribution of Students by Socio- economic Characteristics}

Appendix I reveals the comparative distribution of respondents by their socio-economic characteristics between those who have agripreneurial intentions and those without agripreneurial intentions. The Appendix also presents the equality of variance tests as assessed by Levene's Test for Equality of Variances, and an independent t-test was run on the data with a $95 \%$ confidence interval (CI) for the mean difference. From the Leven's test, the null hypothesis that "there is no significant difference between the variances" is rejected and the alternative hypothesis that there is significant difference between the variances is accepted. Therefore, on the condition that the equality of variances was not assumed, the results showed that monthly expenditure of food spent by students without agripreneurial intention (N6986.67) was significantly higher than that of students with agripreneurial intention $(\mathrm{N} 4906.67)(\mathrm{t}(117.92)=-2.40$; $\mathrm{p}$-value $=0.019)$.

Similarly, on the condition that the equality of variances was not assumed, findings revealed that the monthly expenditure of food health by students with agripreneurial intention (N2095.45) was significantly higher than that of 
students without agripreneurial intention (N871.43) $(\mathrm{t}(49.85)=3.52 ; \mathrm{p}$-value $=0.001)$.

In all other variables, the results from Leven's test shows that the "null hypothesis that there is no significant difference between the variances" cannot be rejected because p-value is greater than 0.05 . On the strength of the results of the t-test equality of means, the differences between the means of other variables listed in Table 1 except the monthly expenditure on food and health were not statistically different between those students with agripreneurial intention and those without agriprenurial intention.

\section{Profile and Respondents'Perception on Mentorship}

Table I shows the Profile and Respondents' Perception on Mentorship. In accordance with the interpretation given in the literature by [59], the mean score (MS) obtained on each of the subscales (SPOL, SPOT and Mentorship) for all respondents was interpreted as follows: when $\mathrm{MS} \leq 2.0$, it is an indication of problem that needs to be urgently addressed; when $2.0<\mathrm{MS}<3.5$, respondents are more positive than negative. However, it is a pointer to the fact that such condition needs to be improved; however, when $\mathrm{MS} \geq 3.5$, it is a reflection of factual positive opinions.

The Mean Score for SPOL, SPOT and Mentorship were found to be between 2.68 and 3.01. This implies that although students are more positive than negative about the quality of learning, quality of their teachers' impact and the impact of their mentors however, despite that, there is a need for improvement.

In SPOL, SPOT and Mentorship subscales, the results from Leven's test indicate that the null hypothesis that there is no significant difference between the variances cannot be rejected because $\mathrm{p}$-value is greater than 0.05 . On this premise, the results of the t-test equality of means are indication that the differences between the means scores for SPOL, SPOT and Mentorship for students with agripreneurial intention were not statistically different from those without agriprenurial intention.

TABLE I: PROFILE AND RESPONDENTS' PERCEPTION ON MENTORSHIP

\begin{tabular}{|c|c|c|c|c|c|c|c|c|}
\hline & & \multirow[t]{2}{*}{ Mean } & & \multicolumn{2}{|c|}{$\begin{array}{c}\text { Levene's Test } \\
\text { for Equality of } \\
\text { Variances } \\
\end{array}$} & \multicolumn{3}{|c|}{ t-test for Equality of Mear } \\
\hline & & & & $\mathrm{F}$ & Sig. & $\mathrm{t}$ & df & $\begin{array}{l}\text { Sig. (2 } \\
\text { tailed }\end{array}$ \\
\hline \multirow{2}{*}{ S1 } & $\mathrm{AI}$ & 2.85 & $\mathrm{~A}$ & 2.21 & .139 & -1.89 & 118 & .060 \\
\hline & NIA & 3.03 & $\mathrm{~B}$ & & & -1.81 & 79.7 & .074 \\
\hline \multirow{2}{*}{$\mathrm{S} 2$} & $\mathrm{AI}$ & 2.68 & A & 2.15 & .144 & -1.62 & 118 & .108 \\
\hline & NIA & 2.78 & $\mathrm{~B}$ & & & -1.65 & 98.7 & .102 \\
\hline \multirow{2}{*}{ M } & $\mathrm{AI}$ & 3.04 & A & .192 & .662 & 0.693 & 118 & .489 \\
\hline & NIA & 2.96 & $\mathrm{~B}$ & & & .696 & 93.9 & .488 \\
\hline \multicolumn{9}{|c|}{$\begin{array}{l}\text { Source: Field Survey, 2021: (S1=SPOL; S2=SPOT; M=Mentorship; } \\
\text { A=Equal Variance Assumed; B=Equal Variance Not Assumed. AI = } \\
\text { Agripreneurial Intention; and NIA = No Agripreneurial Intention). }\end{array}$} \\
\hline
\end{tabular}

Table II presents the distribution of respondents by the status of their mentors/influencers in Agripreneurship development. About $33 \%$ of the students were mentored mainly by freelancers outside academic facility while about $31 \%$ of the students were influenced mainly by the views of their colleagues. It is surprising that only about $11 \%$ of the students were influenced on agripreneurship by their lecturers. This result does not agree with the findings of [20] where most of the students investigated strongly agreed that lecturers and professors' views in South African Universities largely influenced their entrepreneurial intentions. The difference in the findings may not be unconnected to the weakness of adaptive mentorship models in entrepreneurship education in Nigerian tertiary education system. Teachers are supposed to be involved in the mentoring of their students.

\begin{tabular}{ccc}
$\begin{array}{c}\text { TABLE II: DISTRIBUTIONS OF RESPONDENTS BY THE STATUS OF THEIR } \\
\text { MAIN MENTORS/INFLUENCERS IN AGRIPRENEURIAL INTENTIONS }\end{array}$ \\
\hline S/N & $\begin{array}{c}\text { Categories of Agripreneurial } \\
\text { Mentors/Influencers }\end{array}$ & Percentage \\
\hline 1 & Lecturers in your School & 11.11 \\
2 & Parents & 22.22 \\
3 & Freelancers outside academic & 33.33 \\
4 & facility & 31.11 \\
\hline
\end{tabular}

Source: Field Survey, 2021.

\section{E. Student' Perception on Factors Influencing the Development of Agripreneurship in Nigeria}

Table III shows the students' level of agreement on the factors influencing the development of agripreneurship in Nigeria. It shows the students' percentage of agreement to different questions asked to ascertain their perceptions of factors influencing the development of agripreneurship in Nigeria. The perception of students is that "the attributes of potential Agripreneurs (48\%)", "Off school and informal capacity building system" (46\%)", "The economic conditions (level of inflation, tax system, state of economy, etc.) (43\%)", and "positive climate for innovation in businesses and institutions, easy access to resources (41\%)" are the most important factors influencing the development of agripreneurship in Nigeria. However, students' perception on mentorship role in the development of entrepreneurship is $38 \%$. These findings are similar to those of [31], [33], and [20] which harped on the importance of education and attributes of potential agripreneurs to their interest in entrepreneurial intention.

TABLE III: STUDENT' PERCEPTION ON FACTORS INFLUENCING THE DEVELOPMENT OF AGRIPRENEURSHIP IN NIGERIA.

\begin{tabular}{|c|c|c|}
\hline $\mathrm{S} / \mathrm{N}$ & Statements & $\begin{array}{c}\text { Percentage of } \\
\text { agreement }\end{array}$ \\
\hline 1 & The attributes of potential Agripreneurs & 47.92 \\
\hline 2 & $\begin{array}{l}\text { Structure of the Economy and Government } \\
\text { Policy }\end{array}$ & 35.94 \\
\hline 3 & $\begin{array}{l}\text { The economic conditions (level of inflation, } \\
\text { tax system, state of economy, etc.) }\end{array}$ & 43.79 \\
\hline 4 & $\begin{array}{c}\text { Off school and informal capacity building } \\
\text { system }\end{array}$ & 46.19 \\
\hline 5 & $\begin{array}{l}\text { A positive climate for innovation in businesses } \\
\text { and institutions, easy access to resources, etc. }\end{array}$ & 41.11 \\
\hline 6 & $\begin{array}{l}\text { The educational system (relevance of the } \\
\text { available courses, reward for creativity), and } \\
\text { mentorship and other system of support }\end{array}$ & 37.66 \\
\hline
\end{tabular}

Source: Field Survey, 2021.

\section{F. Regression Model showing the Factors Influencing Students' Agripreneurial Intention}

Appendix II reveals the regression model of the factors influencing students' agripreneurial intention. The results showed that number of graduates in the family $(b=-0.370$, $\mathrm{s} . \mathrm{e}=0.167, \mathrm{p}=0.026)$ and mentorship $(\mathrm{b}=-0.981$, s.e $=0.332, \mathrm{p}$ 
$=0.003)$ are negative and significant predictors of the likelihood of students having agripreneurial intention. The odd ratios were indications that as the number of graduates in the family increased, it declined the odds of a student having agripreneurial intention by a factor of 0.691 . Therefore, the result showed that the less the number of graduates in a family, the more a student was likely to be inclined towards having agripreneurial intention.

In similar manner, the results showed that mentorship $(b=-$ 0.981 , s.e $=0.332, \mathrm{p}=0.003$ ) are negative and significant predictors of the likelihood of students having agripreneurial intention. as students expressed stronger positive opinion about mentorship, it declined the odds of a student having agripreneurial intention by a factor of 0.375 . Therefore, the result showed that the less opinion expressed by a student on mentorship, the more a student was likely going to be inclined towards having agripreneurial intention.

Age $(b=0.317$, s.e $=0.100, p=0.02)$, Students' Perception of Learning (SPOL) $(b=0.184$, s.e $=0.036, p=0.001)$ and Students' Perception of Learning (SPOT) and $(b=0.048$, $\mathrm{s} . \mathrm{e}=0.018, \mathrm{p}=0.004)$ are positive and significant predictors of students inclination towards having agripreneurial intentions. The odd ratios indicated that a unit increase in age, SPOL and SPOT increased the odds of a student having agripreneurial intention by a factor of $1.372,1.202$, and 1.050 accordingly. In other words, there was a predicted increase of $31.7 \%, 18.4 \%$, and $4.8 \%$ in the log odds of a student having agripreneurial intention as a result of a unit increase in age, students' perception of learning (SPOL) and Students' Perception of Learning (SPOT) in that order. The implication of this is that an older student and a student who expressed stronger positive opinion about learning (SPOL) and teachers' impact (SPOT) was likely going to have agripreneurial intention.

\section{DISCUSSION}

This study revealed that more male students than female had agripreneurial intentions. This is in line with the findings of [72]. In the literature, men are always willing to take risks and explore new opportunities than women. Since agripreneurship is about innovativeness and risk taking with a view to creating new products and/or services along agricultural value chains [49], it explains why more male students are inclined to having agriprenerial intention than their female counterparts. Except on monthly expenditure on food; and health, the differences in the means of the socioeconomic characteristics between those with and without agripreneurial intentions were not statistically significant. It suggested that that both groups were confronted by the same socio-economic challenges. The study revealed that the average monthly allowances received by students were N8036.67 whereas their average monthly expenses were N27266.83 giving a deficit of N19,230.16 (debt or transfer or gifts). Experts have found that debt impaired students learning and the choice of career they make $[60,61]$. In view of this huge monthly income deficit, the average monthly amount spent on food was found to be ridiculously low [N6206.67 (\$0.542/day)]. This affirms high poverty level in Nigeria [75], and particularly showing that there is pronounced hunger among undergraduates in Nigeria [62,
63]. In the literature, it is well established that hunger is significantly influenced by low monthly (stipend) income, cost of food, and sources of income, which in turn affect students' learning process $[64,65]$. The mental stress arising from these, to a large extent, limits students' self - efficacy and business skills cognitive functions [66], which also affects students' entrepreneurial intentions [67]. Furthermore, perceptions of students with and without agripreneurial intentions about their quality of learning (SPOL), teachers' impact (SPOT) and mentorship are not statistically different between the two groups. Despite more positive perceptions than negative perceptions, the mean score indicated that there is need to improve the Faculty of Agriculture in both institutions in the area of SPOL, SPOT and mentoring skills of teachers. Quality learning and teaching of entrepreneurship is a precursor to agripreneurship development [68] and [69]. The negative impact of mentorship tells a lot about the source of mentoring. The result in this study negates the finding of [20] where teachers are major influencers of students' entrepreneurial intentions. In this study, the two major factors influencing agripreneurship development in Nigeria in the perspective of students are: the attributes of potential Agripreneurs (48\%), and the off school and informal capacity building system (46\%). However, students' low perception of the contribution of educational system and associated support system agripreneurship development in Nigeria is an evidence of deteriorating academic motivation which has not only affected agripreneurship development but professional development [70]. It suggests needs for tremendous improvement in the following areas: the educational system, economic conditions, and structure of the economy \& government policy to take more prominent roles in agripreneurship development in Nigeria. This study also found that number of graduates in the family and mentorship reduced a student's likelihood to have agripreneurial intention. One is surprised that despite the poor economic situation in the country, many are still not willing to become entrepreneur due to difficult and highly risky business environment. In most cases, the older graduates offer discouraging advice on agripreneurship. As students grows older, they gain experience and become more mature to take responsibilities for their actions and inactions. Therefore, decisions taken by older students are likely going to be from the informed point of view. SPOL and SPOT have positive and significant influence on agripreneurial decision of students. This finding agrees with that of [71], who found that students' entrepreneurial intention was being influenced by, among other factors, educational and concept development supports. This suggests that as students are exposed to quality learning and quality teaching, their development and their decision making process especially as it relates job satisfaction and happiness are enhanced. Interventions that improve the quality of learning and teaching will motivate students towards having agripreneurial intentions \& systematically solve the succession problem in the sector [74]. 


\section{CONCLUSION}

This study examined the agripreneurial intentions among Agricultural students of state owned institutions in Ondo State owned tertiary institutions. In the opinions of the students their agripreneurship interests were largely influenced by freelancers and their colleagues. The place of their teacher was missing among their mentors. The study also found that both quality of learning and quality of teachers have positive and statistically significant but very weak effect on students' likelihood to have agripreneurial intention. On the other hand, increase in the scores of students' perception of mentorship declined their likelihood to have agripreneurial intention. Evidence from the study showed that poverty and hunger were highly pronounced among the students, who receive little monthly allowances and feed on less than $\$ 1 /$ day. This is a disincentive to learning and thus, it should be addressed with appropriate policy strategy. In clear terms, improving quality of learning and university teachers' impact in the area of providing motivations to arouse students' interests in agripreneurship is an appropriate strategy to reduce youth unemployment, tackle hunger and poverty among the youths in Nigeria. In this way, the over-bloated Nigerian labour market can be drastically reduced.

APPENDIX

APPENDIX I: Comparative Distribution of Students by Socio-economic Characteristics

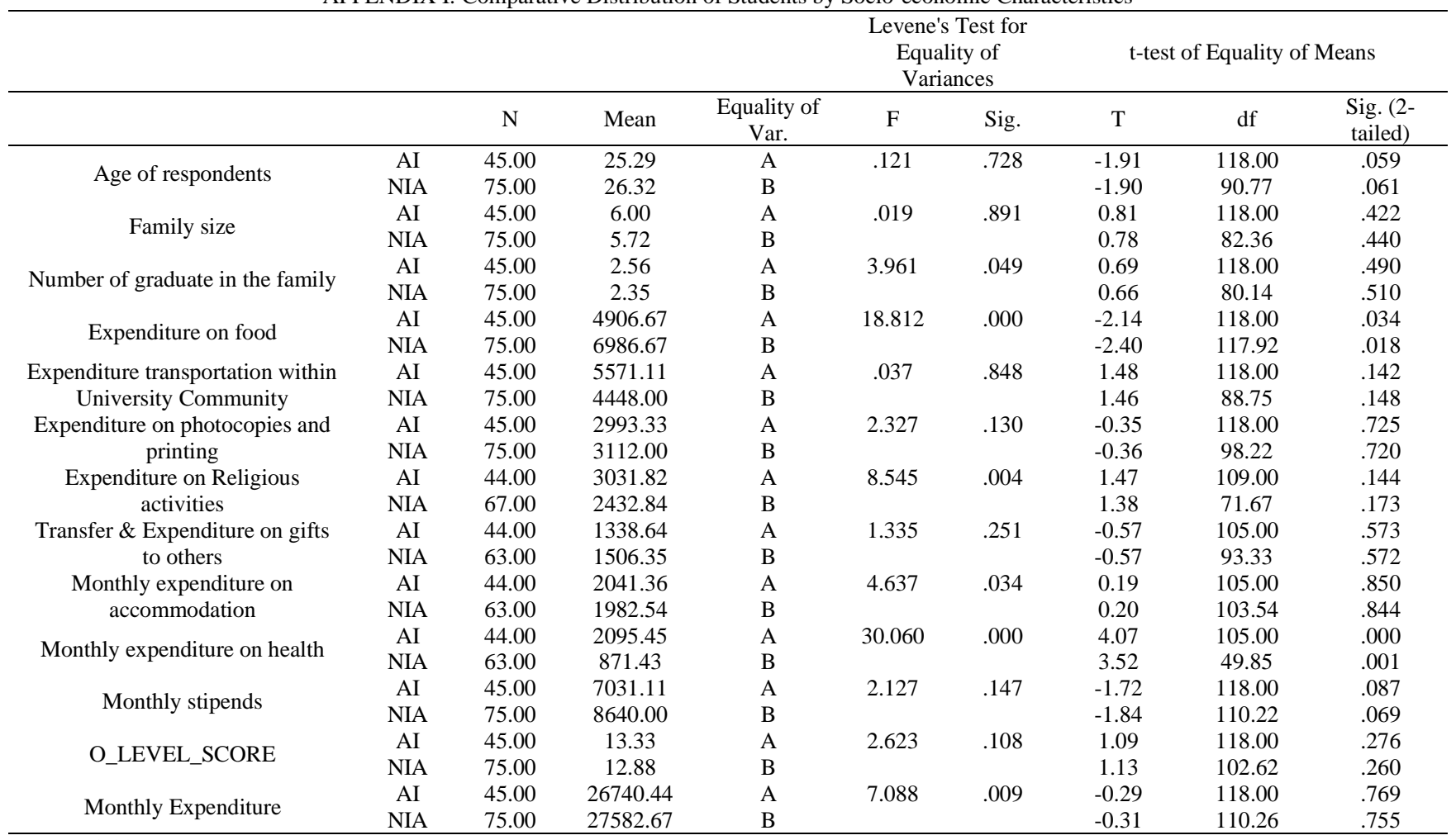

Source: Field Survey, 2021

( $A=$ Equal Variance Assumed; B=Equal Variance Not Assumed. AI = Agripreneurial Intention; and NIA = No Agripreneurial Intention $)$.

APPENDIX II: Regression Model showing the Factors Influencing Students'Agripreneurial Intention

\begin{tabular}{|c|c|c|c|c|c|c|c|c|}
\hline \multirow{2}{*}{ Parameter } & \multirow{2}{*}{ B } & \multirow{2}{*}{$\begin{array}{l}\text { Std. } \\
\text { Error }\end{array}$} & \multicolumn{2}{|c|}{$\begin{array}{c}95 \% \text { Wald } \\
\text { Conf. Interval }\end{array}$} & \multicolumn{2}{|c|}{$\begin{array}{c}\text { Hypothes } \\
\text { Test }\end{array}$} & \multirow[b]{2}{*}{ Sig. } & \multirow{2}{*}{$\operatorname{Exp}(B)$} \\
\hline & & & Lower & Upper & $\begin{array}{c}\text { Wald } \\
\text { ChiSquare }\end{array}$ & df & & \\
\hline (Intercept) & -0.718 & 0.151 & $\begin{array}{c}- \\
14.077\end{array}$ & -0.159 & 9.805 & 1.000 & 0.002 & 0.488 \\
\hline $\begin{array}{c}\text { [gender }=1.00 \\
]\end{array}$ & -0.353 & 0.483 & -1.299 & 0.593 & 0.535 & 1.000 & 0.465 & 0.703 \\
\hline $\begin{array}{c}\text { No of Grad in the } \\
\text { Family }\end{array}$ & -0.370 & 0.167 & -0.697 & -0.043 & 4.932 & 1.000 & 0.026 & 0.691 \\
\hline Age & 0.317 & 0.100 & 0.120 & 0.513 & 9.958 & 1.000 & 0.002 & 1.372 \\
\hline Mentorship & -0.981 & 0.332 & -3.220 & -0.742 & 9.823 & 1.000 & 0.003 & 0.375 \\
\hline SPOL & 0.184 & 0.036 & 0.742 & 3.625 & 8.814 & 1.000 & 0.001 & 1.202 \\
\hline SPOT & 0.048 & 0.018 & -0.473 & 2.570 & 1.824 & 1.000 & 0.004 & 1.050 \\
\hline CGPA & -0.381 & 0.4199 & -1.204 & 0.442 & 0.822 & 1.000 & 0.365 & 0.683 \\
\hline
\end{tabular}

Source: Field Survey, 2021. 


\section{REFERENCES}

[1] Nyoni, T. (2019). Population Explosion in Nigeria by 2050: Overwhelming Empirical Evidence from The Box-Jenkins ARIMA Approach. Dimorian Review, 6(2), 15-27.

[2] International Monetary Fund, (2015): Promoting Economic Transformation in Nigeria. IMF Country Report No. 15/85

[3] Rukuni, M., \& Zvavanyange, R. (2014). Re-configuring the future of Africa's workforce in agriculture and food systems with youth in mind. Nature \& Faune, 28(1), 26-29.

[4] Koira, A. (2014). Agribusiness in sub-Saharan Africa: pathways for developing innovative programs for youth and the rural poor. Agribusiness in sub-Saharan Africa: pathways for developing innovative programs for youth and the rural poor. Working Paper.

[5] Agricultural Policy, Productivity and Poverty: The Critical Nexus. (Unpublished Inaugural Lecture Series 69, The Federal University of Technology, Akure. pp. 1-6.

[6] Ajibefun, I. A., \& Daramola, A. G. (2003). Determinants of technical and allocative efficiency of micro-enterprises: firm-level evidence from Nigeria. African development review, 15(2-3), 353-395.

[7] Eresia-Eke, C., \& Gunda, C. (2015). The entrepreneurial intentions of University of Botswana students. Problems and perspectives in management, (13, Iss. 3), 55-65.

[8] Carr, S., \& Roulin, A. (2016). An exploration of Agripreneurship, Scope, Actors and Prospects. Agenda, 2063, 16.

[9] Uche, C., \& Familusi, L. C. (2018). The adoption of agripreneurship as a mitigating measure to unemployment in Nigeria: a topical review. Global Journal of Management and Business Research. https://globaljournals.org/GJMBR_Volume18/3-The-Adoption-ofAgripreneurship.pdf.

[10] Alexandra Chimona (2020). Agripreneurship: The Agricultural Entrepreneurship. Institute of Entrepreneurship Development (iED).

[11] Gartner, W. B. (1988). "Who is an entrepreneur?" is the wrong question. American journal of small business, 12(4), 11-32.

[12] Liverpool-Tasie. L.S.O. et al. (2020) Spillover Effects of MediumScale Farms on Smallholder Behaviour and Welfare: Evidence from Nigeria, Working Paper 38, Brighton: Future Agricultures Consortium.

[13] Krueger Jr, N. F., \& Brazeal, D. V. (1994). Entrepreneurial potential and potential entrepreneurs. Entrepreneurship theory and practice, 18(3), 91-104.

[14] Thompson, E. R. (2009). Individual entrepreneurial intent: Construct clarification and development of an internationally reliable metric. Entrepreneurship Theory and Practice, Vol. 33, No. 3, pp. 669-694.

[15] Guth, W. D., \& Ginsberg, A. (1990). Guest editors' introduction: Corporate entrepreneurship. Strategic management journal, 5-15.

[16] Shane, S., \& Venkataraman, S. (2000). The promise of entrepreneurship as a field of research. Academy of management review, 25(1), 217-226.

[17] Olomu, M.O., Ekperiware, M.C. and Akinlo, T. (2020), "Agricultural sector value chain and government policy in Nigeria: issues, challenges and prospects", African Journal of Economic and Management Studies, Vol. 11 No. 3, pp. 525-538. https://doi.org/10.1108/AJEMS-03-20190103.

[18] Shepherd, D. A., Williams, T. A., \& Patzelt, H. (2015). Thinking about entrepreneurial decision making: Review and research agenda. Journal of management, 41(1), 11-46.

[19] Katz, J., \& Gartner, W. B. (1988). Properties of emerging organizations. Academy of management review, 13(3), 429-441.

[20] Iwu, Chux Gervase Ikechukwu .O. Ezeuduji, Chukuakadibia EresiaEke, Robertson K. Tengeh. "The Entrepreneurial Intention of University Students: The Case of a University of Technology in South Africa". Acta Universitatis Danubius. OEconomica 1:164-181. http:www.ceeol.com/search/article-detail?id=517515.

[21] Ikuemonisan, Edamisan Stephen (2021). Influence of Agricultural Degree Programme Environment on students' career Preference in Agribusiness in Nigeria. Unpublished Policy Brief submitted to IITA.

[22] Gaweâ, A. (2010). "The Relationship between Entrepreneurship and Unemployment in the Business Cycle", Journal of International Studies, Vol. 3, No 1, 2010, pp. 59-69. https://media.proquest.com/media/hms/PFT/1/dNa8F?_s=c\%2BSkD $\% 2$ FgalXd4T75NOdTIxtOKc88\%3D.

[23] Parker, S. C. (2006). Entrepreneurship, self-employment and the labour market. Oxford handbook of entrepreneurship, 435-460.

[24] [24] Knight, F. H. (1921). Risk, uncertainty and profit (Vol. 31). Houghton Mifflin. 273.

[25] Liñán, F. \& Chen, Y. (2006). Testing the entrepreneurial intention model on a two-country sample. Document de Treball d'economica dell'empresa, num 06/7. Universitat Autooma de Barcelona.

[26] Liñán, F. \& Chen, Y.W. (2009). Development and cross-cultural application of a specific instrument to measure entrepreneurial intentions. Entrepreneurship Theory and Practice, Vol. 33, No. 3, pp. 593-617.

[27] European Commission (2012). Effects and impact of entrepreneurship programmes in higher education. European Commission: Brussels.

[28] Douglas, E. J., \& Shepherd, D. A. (2000). Entrepreneurship as a utility maximizing response. Journal of business venturing, 15(3), 231-251.

[29] Campbell, B. A., Ganco, M., Franco, A. M., \& Agarwal, R. (2012). Who leaves, where to, and why worry? Employee mobility, entrepreneurship and effects on source firm performance. Strategic Management Journal, 33(1), 65-87.

[30] Nwosu, J. C., John, H. C., Izang, A. A., \& Akorede, O. J. (2018). Assessment of information and communication technology (ICT) competence and literacy skills among undergraduates as a determinant factor of academic achievement. Educational Research and Reviews, 13(15), 582-589.

[31] Zhang, Y., Duysters, G. \& Cloodt, M. (2014). The role of entrepreneurship education as a predictor of university students' entrepreneurial intention. International Entrepreneurship and Management Journal, Vol. 10, pp. 623-641.

[32] Hattab, H. W. (2014). Impact of entrepreneurship education on entrepreneurial intentions of university students in Egypt. The Journal of Entrepreneurship, 23(1), 1-18.

[33] Solesvik, M., Westhead, P. \& Matlay, H. (2014). Cultural factors and entrepreneurial intention: The role of entrepreneurship education. Education + Training, Vol. 56, No. 8/9, pp. 680-696.

[34] Ajzen, I. (1991). The theory of planned behavior. Organizational Behavior and Human DecisionProcesses, Vol. 50, No. 2, pp. 179-211.

[35] Lee, S.H., \& Wong, P.K. (2004). An exploratory study of technopreneurial intentions: A career anchor perspective. Journal of Business Venturing, Vol. 19, No. 1, pp. 7-28.

[36] Pillai, R. (2010). Labour Market Structure: A Brief Literature Survey. Online at https://mpra.ub.uni-muenchen.de/27479/ MPRA Paper No. 27479, posted 20 Dec 2010 02:10 UTC.

[37] Thurik, A. R., Carree, M. A., Van Stel, A., \& Audretsch, D. B. (2008). Does self-employment reduce unemployment? Journal of Business Venturing, 23(6), 673-686.

[38] Block, J., \& Koellinger, P. (2009). I can't get no satisfactionNecessity entrepreneurship and procedural utility. Kyklos, 62(2), 191209.

[39] Lynde, R. (2020). Innovation \& entrepreneurship driving food system transformation. Physiology \& behavior, 220, 112866.

[40] Hessels, J., Van Gelderen, M., \& Thurik, R. (2008). Entrepreneurial aspirations, motivations, and their drivers. Small business economics, 31(3), 323-339.

[41] Achim, W., Robert, F., Robert, H., \& Nina B. (2017). Smart farming is key to developing sustainable agriculture. PNAS, 114(24), 6148-6150.

[42] Price water house Coopers LLP (PwC). (2016). PwC Agribusiness report. African Press Organization.

[43] Emami, M., Almassi, M., \& Bakhoda, H. (2018). Agricultural mechanization, a key to food security in developing countries: strategy formulating for Iran. Agriculture \& Food Security, 7(1), 1-12.

[44] Bell, D. E., \& Scott, C. (2011). Los Grobo: Farming's Future? Harvard Business School General Management Unit Case, (511- 088).

[45] Saiz-Rubio, V., \& Rovira-Más, F. (2020). From smart farming towards agriculture 5.0: A review on crop data management. agronomy, 10(2), 207.

[46] Mellor, J. W. (2017). Agricultural development and economic transformation: promoting growth with poverty reduction. Springer. Palgrave Studies in Agricultural Economics and Food Policy. pp: 259 https://doi.org/10.1007/978-3-319-65259-7.

[47] Regan, Á., Stuart, G., \& Paul, M. (2018). Smart farming in Ireland: Anticipating positive and negative impacts through a qualitative study of risk and benefit perceptions amongst expert actors in the Irish agrifood sector. Conference proceedings of 13th European International Farm Systems Association Symposium.

[48] Lytos, A., Lagkas, T., Sarigiannidis, P., Zervakis, M., \& Livanos, G. (2020). Towards smart farming: Systems, frameworks and exploitation of multiple sources. Computer Networks, 172, 107147.

[49] Omodanisi, E. O., Egwakhe, A. J., \& Ajike, O. E. (2020) Smart Agripreneurship: A Panacea for Food Security In Nigeria. IOSR Journal of Business and Management (IOSR-JBM) e-ISSN 2278487X, p-ISSN: 2319-7668. Volume 22, Issue 3. Ser. V (March 2020), PP 65-74. https://www.iosrjournals.org/iosr-jbm/papers/Vol22 issue3/Series-5/H2203056574.pdf.

[50] Adejumo, A. A. (2008), Processing, Marketing and Utilization of African Locust Bean (ParkiaBiglobosa, Jacque Benth) in Arigid Akoko, Ondo State: Implications for Poverty Reduction, A Dissertation, Department of Forest Resources Management, University of Ibadan. 
[51] National Population Commission, NPC. (2006). Nigerian population census report 2006.

[52] Veal, A.J. (2011). Research methods for leisure and tourism: A practical guide (4th Ed.). Harlow, UK: Financial Times Prentice Hall.

[53] Bateman, J., Carson, R. T., Day, B., Hanemann, W. M., Hanley, N., Hett, H., Lee, M. J., Loomes, G., Mourato, S., Özdemiroglu, E., Pearce, W. D., Elgar, E. (2002), Economic valuation with Stated Preference Techniques: A Manual, Edward Elgar Publishing, Inc.

[54] Yoo, D. M., \& Kim, D. H. (2019). The relationship between students' perception of the educational environment and their subjective happiness. BMC medical education, 19(1), 409.

[55] Sweeney, B. (2004), Ask the mentor of mentors: a collection of answers to frequently asked questions, http://teachermentors.com/RSOD\%20Site/AskMOM.html.

[56] Okurame, D. E. (2008). Mentoring in the Nigerian academia: experiences and challenges. International Journal of Evidence Based Coaching \& Mentoring, 6(2).

[57] Umukoro, O. S., \& Okurame, D. E. (2018). Role of mentoring in career adaptability and ambiguity tolerance of potential Nigerian entrepreneurs: the moderating effect of age. Journal of Global Entrepreneurship Research, 8(1), 1-13.

[58] Sullivan, K. R., \& Mahalik, J. R. (2000). Increasing career self-efficacy for women: Evaluating a group intervention. Journal of Counseling \& Development, 78(1), 54-62.

[59] McAleer S and Roff S (2001) A practical guide to using the Dundee Ready Education Environment Measure (DREEM). In: Genn JM (Ed). AMEE Medical Education Guide No.23 Curriculum, environment, climate, quality and change in medical education; A unifying perspective. Dundee (UK): Association of Medical Education in Europe. Pp. 29- 33.

[60] Sieg, H., \& Wang, Y. (2018). The impact of student debt on education, career, and marriage choices of female lawyers. European Economic Review, 109, 124-147.

[61] Kenny, D. T. (2010). The Effect of Student Debt on Career Choices (Doctoral dissertation, Boston College. College of Arts and Sciences). $\mathrm{Pp}: 1-56$

[62] Ukegbu, P., Nwofia, B., Ndudiri, U., Uwakwe, N., \& Uwaegbute, A. (2019). Food insecurity and associated factors among University Students. Food and nutrition bulletin, 40(2), 271-281.

[63] Etim, E. E., Duke, O. O., \& Ogbinyi Jr, O. J. (2017). The implications of food insecurity, poverty and hunger on Nigeria's national security. Asian Research Journal of Arts \& Social Sciences, 110.

[64] Deeds, C. (2015, August). Food for thought: How food insecurity affects a child's education. In Washington, DC: American Youth Policy Forum.

[65] Afridi, Farzana and Barooah, Bidisha and Somanathan, Rohini, Hunger and Performance in the Classroom. IZA Discussion Paper No. 12627, Available at SSRN: https://ssrn.com/abstract=3457671.

[66] Cibrian-Llanderal, T., Melgarejo-Gutierrez, M., \& HernandezBaltazar, D. (2018). Stress and Cognition: Psychological basis and support resources. Health and Academic Achievement, 11. Cooney, T. M. (2012). Entrepreneurship skills for growth-orientated businesses. In Report for the Workshop on 'Skills Development for SMEs and Entrepreneurship (Vol. 28).

[67] Molaei, R., Reza Zali, M., Hasan Mobaraki, M. and Yadollahi Farsi, J. (2014), "The impact of entrepreneurial ideas and cognitive style on students' entrepreneurial intention", Journal of Entrepreneurship in Emerging Economies, Vol. 6 No. 2, pp. 140162. https://doi.org/10.1108/JEEE-09-2013-0021.

[68] Boldureanu, G., Ionescu, A. M., Bercu, A. M., Bedrule-Grigoruță, M. V., \& Boldureanu, D. (2020). Entrepreneurship education through successful entrepreneurial models in higher education institutions. Sustainability, 12(3), 1267.

[69] Diegoli, R. B., \& Gutierrez, H. S. M. (2018). Teachers as entrepreneurial role models the impact of a teacher's entrepreneurial experience and student learning styles in entrepreneurial intentions. Journal of Entrepreneurship Education, 21(1), 1-11.

[70] Lee Y. M. (2018). It is time to reconsider the unnecessary division of premedical and medical studies. Korean J Med Educ; 30(4):279-281. doi: $10.3946 / \mathrm{kjme} .2018 .102$.

[71] Moraes, G. H. S. M. D., Iizuka, E. S., \& Pedro, M. (2018). Effects of entrepreneurial characteristics and university environment on entrepreneurial intention. Revista de Administração Contemporânea, 22(2), 226-248.

[72] Harris, C. R., \& Jenkins, M. (2006). Gender differences in risk assessment: why do women take fewer risks than men?.

[73] IBM Corp. Released 2015. IBM SPSS Statistics for Windows, Version 23.0. Armonk, NY: IBM Corp.

[74] Laud, K. (2018). Factors influencing agri-preneurship and their role in agripreneurship performance among young graduate agripreneurs.
International Journal of Environment, Agriculture and Biotechnology, $3(6), 1878-2456$

[75] World Bank. (2020). Monitoring global poverty. Report of Commission on Global Poverty. https://openknowledge.worldbank.org/handle/10986/25141.

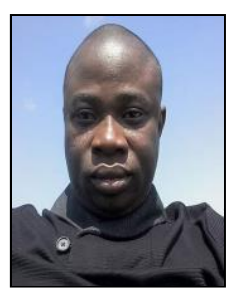

Dr E. S. Ikuemonisan is an Agricultural Economist specializing in Agricultural Marketing and Agricultural Development \& Policy. After the mandatory One-year National Youth Service as School Teacher, he worked briefly as Divisional Estate Manager in Okitipupa Oil Palm Company PLC and was in charge of engaging community people to settle agitations over land compensation and corporate social performance issues. His quest for scholastic laurels challenged him to further his studies and this culminated into obtaining the M. Tech (Agricultural Economics) in 2012. After completing the course-work of the Master's degree programme, he took up appointment as Engagements Manager with MAFTOE Research and Capacity Building Consult, Akure. At MAFTOE, he consolidated on his research skills and how to apply it to executing consultancies for various organizations. He later secured a permanent employment as a Planning Officer in charge of Capacity Building and Monitoring at the Ondo State Ministry of Economic Planning and Budget (MEPB) and thus converted his appointment with MAFTOE to part-time Key Expert position. From MEPB, he was later seconded to the Ministry of Agriculture and Natural Resources where he was in charge of monitoring and evaluation of the Ministry's budget implementation and other related government businesses. His experience with MAFTOE motivated him to enroll into the $\mathrm{PhD}$ programme which he earned in 2019. While on the PhD programme, he won the highly competitive split-site scholarship of the Tertiary Education Trust Fund in 2017 to complete his data analysis and report write-up at the Department of Agricultural Economics and Rural Sociology, Auburn University, USA. At present, he is a Lecturer II. In his research and consultancy execution experience, he has served as enumerator, survey team supervisor, research assistant that performed, at one time or the other, the role of data gathering, entry, analysis, report drafting and presentations in socio-economic surveys that included on land issues. Dr Ikuemonisan is highly conversant with Agribusiness and Enterprise Management having taught these course and researched in the same fields for over five years. $\mathrm{He}$ has also won fellowships, research and travel grants to conduct research and present the outcomes of his studies in international academic gatherings. In 2020, he won a fellowship/research grant to promote "Youth Engagement in Agribusiness and Rural Economic Activities in Africa" funded by International Fund for Agricultural Development (IFAD). The research is ongoing. Dr Ikuemonisan has more than 10 academic publications in competitive. 